\title{
Effect of Growth Temperature and Culture Age on the Lipid Composition of Vibrio cholerae 569 B (Inaba)
}

\author{
By S. RAZIUDDIN \\ Department of Biochemistry, Hiroshima University School of Medicine, \\ Hiroshima-734, Japan
}

(Received I8 November I975; revised I2 January 1976)

SUMMARY

The relative amounts of the major phospholipids (phosphatidylethanolamine, phosphatidylglycerol and lyso-phosphatidylethanolamine) and fatty acids in Vibrio cholerae 569B (Inaba) varied with growth temperature and between exponential and stationary phases of growth.

\section{INTRODUCTION}

The lipid composition of bacteria is a function of such parameters as growth rate (Cronan, I968; De Siervo, 1969; Randle, Albro \& Dittmer, I969; Oliver \& Colwell, I973), medium composition (Munro \& Bell, I973; Minnikin, Abdolrahimzadeh \& Baddiley, I97I; Gill, 1975), $\mathrm{pH}$ of the culture (Minnikin \& Abdolrahimzadeh, 1974) and growth temperature (De Siervo, 1969; Russell, I97I ; Cullen, Phillips \& Shipley, I97I ; Hunter \& Rose, 1972; Gill, 1975). Since most of the lipids are in the membranes, it is likely that these environmentally-induced changes have major physiological significance. The effects of culture age and growth temperature on the lipid content of bacteria are also important, because it is a common practice in experiments to use cells in the exponential phase of growth when they are physiologically most active, or in the stationary phase when the greatest cell mass is obtained. This paper describes the effects of culture age and growth temperature on the phospholipid and fatty-acid composition of Vibrio cholerae 569B (Inaba).

\section{METHODS}

Organism and growth. Vibrio cholerae 569B (Inaba) was grown in a synthetic medium containing (g 1-1): $\mathrm{K}_{2} \mathrm{HPO}_{4}, \mathrm{I} \cdot 0 ;\left(\mathrm{NH}_{4}\right)_{2} \mathrm{SO}_{4}, \mathrm{I} \cdot 0 ; \mathrm{NaCl}, \mathrm{I0} ; \mathrm{Na}_{2} \mathrm{~S}_{2} \mathrm{O}_{3}, \mathrm{I} \cdot 0 ; \mathrm{MgCl}_{2}, 0.048$; L-histidine, 0.23 ; asparagine, 0.5 ; and glutamic acid, 0.5 . The medium was dispensed in $100 \mathrm{ml}$ portions in $250 \mathrm{ml}$ Erlenmeyer flasks; glucose was autoclaved separately and added to a final concentration of $0.1 \%(\mathrm{w} / \mathrm{v})$. Flasks were incubated on a rotary shaker at $100 \mathrm{rev} . / \mathrm{min}$ at $27^{\circ} \mathrm{C}$ or $37^{\circ} \mathrm{C}$. Cultures at the desired growth phase were harvested by centrifuging at $4{ }^{\circ} \mathrm{C}$ and washed once with distilled water before extracting the lipids.

Extraction, separation and analysis of lipids. Lipids were extracted by the modified Bligh \& Dyer (1959) procedure described by Rizza, Tucker \& White (1970). A suspension of bacteria (approx. $25 \mathrm{mg}$ dry wt) in $50 \mathrm{~mm}$-sodium phosphate buffer, $\mathrm{pH} 7.6$ (50 ml) was mixed with methanol (100 $\mathrm{ml})$ and chloroform $(50 \mathrm{ml})$, shaken vigorously and allowed to stand overnight. Chloroform $(50 \mathrm{ml})$ and $50 \mathrm{ml}$ of $\mathrm{I} \cdot 0 \mathrm{M}-\mathrm{KCl}$ solution containing $0.4 \%$ $(v / v)$ glacial acetic acid were then added and the mixture shaken. After several hours, the 
mixture separated into two phases: the lower layer, containing the lipid, was filtered through a Whatman no. 12 filter paper.

Neutral lipids were separated by silicic-acid column chromatography according to the method of Vorbeck \& Marinetti (1965). They were resolved on thin layers of activated silica-gel G using hexane-diethyl ether (IO:I, by vol.) as solvent. Phospholipids were separated on thin layers of activated silica-gel $H$ using the following solvent systems: chloroform-methanol-water $(65: 25: 4$, by vol.); chloroform-methanol-acetic acid (65:25:8, by vol.); chloroform-methanol-7 M-ammonia (65:35:4, by vol.); chloroformmethanol-acetic acid-water (50:25:7:3, by vol.).

Phospholipids were located on dried chromatograms by iodine vapour and rhodamine $6 \mathrm{G}$ staining. Tests for amino, phosphate and vicinal hydroxyl groups were also performed (Marinetti, 1962; Ansell \& Hawthorne, 1964; Vorbeck \& Marinetti, 1965). Chemical tests and mobilities of the lipid components were compared with those of several commercial phospholipids. Lipid phosphorus was determined by the method of Bartlett (1959). The distribution of fatty acids in phosphatidylethanolamine was determined by hydrolysis at the 2 position using Crotalus adamanteus venom phospholipase $\mathrm{A}_{2}$ (Sigma), as described by Hildebrand \& Law (1964).

The fatty-acid compositions of the total lipids and of phosphatidylethanolamine, the main phospholipid, were determined by gas-liquid chromatography of the methyl esters, prepared by trans-esterification of lipid using $10 \%(\mathrm{w} / \mathrm{v})$ boron trifluoride (Morrison \& Smith, 1964). Measurements were made on an FB4 gas chromatogram (Shandon Southern Instruments Ltd, Camberley, Surrey) under the following conditions: column packing, $15 \%(\mathrm{w} / \mathrm{v})$ ethylene glycol succinate (EGS) polyester on chromosorb W (80 to 100 mesh); column length, $5 \mathrm{ft}$ ( $\mathrm{I} \mathrm{I} 8 \mathrm{~cm}$ ), with $4 \mathrm{~mm}$ internal diameter; column temperature, $190{ }^{\circ} \mathrm{C}$; detector temperature, $210^{\circ} \mathrm{C}$; argon flow rate, 30 to $60 \mathrm{ml} \mathrm{min}^{-1}$. The fatty-acid methyl esters were identified by comparing their retention times with those of standard compounds of known purity. Relative proportions of the fatty acids were calculated from their respective peak areas, estimated from peak height $\times$ peak width at half height.

\section{RESULTS}

The phospholipids that were identified and estimated in V. cholerae 569B (Inaba) were phosphatidylethanolamine, phosphatidylglycerol, lyso-phosphatidylethanolamine, phosphatidylserine and cardiolipin. Thin-layer chromatography of the neutral lipid fraction showed the presence of free fatty acids only. The fatty-acid composition of whole cell extractable lipid, neutral lipid and phospholipid showed the presence of $C_{12: 0}, C_{14: 0}, C_{15: 0}$, $\mathrm{C}_{16: 0}, \mathrm{C}_{16: 1}, \mathrm{C}_{17: 0}, \mathrm{C}_{18: 0}$, and $\mathrm{C}_{18: 1}$ fatty acids. Changing the growth medium from nutrient agar to synthetic salts medium did not significantly change the spectrum of phospholipids or the fatty-acid composition (Raziuddin \& Ambegaokar, 1976). Cyclopropane and hydroxy acids were absent from free lipids of $V$. cholerae; although hydroxy acids are present in lipopolysaccharide and lipid A (Raziuddin \& Kawasaki, 1976).

The effects of the growth temperature and culture age on the relative phospholipid composition of $V$. cholerae are shown in Table I. Decreasing the temperature increased the relative proportions of lyso-phosphatidylethanolamine and cardiolipin while those of phosphatidylethanolamine and phosphatidylglycerol decreased and phosphatidylserine remained unchanged. In stationary-phase cultures, there was a greater proportion of phosphatidylethanolamine and a smaller proportion of phosphatidylglycerol than in exponential-phase cultures at the same temperature, and cardiolipin was not detected at all. 


\section{Table I. Effect of growth temperature and phase of growth on the phospholipid composition of Vibrio cholerae 569в (Inaba)}

The phospholipids were separated by thin-layer chromatography in chloroform-methanol-water (65:25:4, by vol.), and the total lipid phosphorus and the phosphorus content of the individual components were estimated as described in Methods. The results are the average of three separate determinations in which individual quantities did not differ by more than $1.5 \%$ of the total phosphorus present in the major phospholipids.

\begin{tabular}{|c|c|c|c|c|c|c|}
\hline \multirow[b]{2}{*}{$\begin{array}{l}\text { Growth } \\
\text { phase }\end{array}$} & \multirow[b]{2}{*}{$\begin{array}{l}\text { Temp- } \\
\text { erature } \\
\left({ }^{\circ} \mathrm{C}\right)\end{array}$} & \multicolumn{5}{|c|}{ Phospholipids (\%,w/w, total lipid phosphorus) } \\
\hline & & $\begin{array}{l}\text { Phosphatidyl- } \\
\text { ethanolamine }\end{array}$ & $\begin{array}{l}\text { Phosphatidyl- } \\
\text { glycerol }\end{array}$ & $\begin{array}{l}\text { Lyso- } \\
\text { phosphatidyl- } \\
\text { ethanolamine }\end{array}$ & $\begin{array}{l}\text { Phosphatidyl- } \\
\text { serine }\end{array}$ & $\begin{array}{l}\text { Cardio- } \\
\text { lipin }\end{array}$ \\
\hline Exponential & 37 & 68 & 21 & $8 \cdot 6$ & 0.8 & 0.6 \\
\hline & 27 & 54 & $17 \cdot 5$ & $19 \cdot 0$ & 0.7 & $2 \cdot 5$ \\
\hline Stationary & 37 & $75 \cdot 5$ & $16 \cdot 8$ & $3 \cdot 6$ & 0.8 & - \\
\hline
\end{tabular}

Table 2. Effect of growth temperature and phase of growth on the fatty-acid composition of the total lipids of Vibrio cholerae 569B (Inaba)

\begin{tabular}{|c|c|c|c|c|c|c|c|c|c|c|c|}
\hline \multirow[b]{2}{*}{$\begin{array}{l}\text { Growth } \\
\text { phase }\end{array}$} & \multirow[b]{2}{*}{$\begin{array}{l}\text { Temp- } \\
\text { erature } \\
\left({ }^{\circ} \mathrm{C}\right)\end{array}$} & \multicolumn{10}{|c|}{ Fatty acids* $(\%, w / w$, total fatty acids $)$} \\
\hline & & $12: 0$ & 14:0 & 15:0 & $16: 0$ & I6:I & $17: 0$ & $18: 0$ & I8:I & $\begin{array}{l}\text { Total } \\
\text { sat- } \\
\text { urated }\end{array}$ & $\begin{array}{l}\text { Total } \\
\text { unsat- } \\
\text { urated }\end{array}$ \\
\hline Exponential & $\begin{array}{l}37 \\
27\end{array}$ & $\begin{array}{l}1 \cdot 2 \\
0.8\end{array}$ & $\begin{array}{l}4 \cdot 8 \\
3 \cdot 0\end{array}$ & $\begin{array}{l}0.8 \\
0.7\end{array}$ & $\begin{array}{l}19 \cdot 2 \\
23 \cdot 0\end{array}$ & $\begin{array}{l}52 \cdot 8 \\
40 \cdot 7\end{array}$ & $\begin{array}{l}0.5 \\
0.5\end{array}$ & $\begin{array}{l}0 \cdot 8 \\
I \cdot 0\end{array}$ & $\begin{array}{l}17 \cdot 5 \\
30 \cdot 2\end{array}$ & $\begin{array}{l}27 \cdot 3 \\
29 \cdot 0\end{array}$ & $\begin{array}{l}70 \cdot 3 \\
70 \cdot 9\end{array}$ \\
\hline Stationary & 37 & 1.0 & $2 \cdot 8$ & 0.6 & $20 \cdot 4$ & $36 \cdot 5$ & 0.8 & 0.6 & $36 \cdot 2$ & $26 \cdot 2$ & $72 \cdot 7$ \\
\hline
\end{tabular}

* Number preceding the colon indicates the number of carbon atoms; number after the colon designates the degree of unsaturation.

The proportion of phosphatidylserine was the same in both exponential and stationary growth phases.

Table 2 shows data on the fatty-acid composition of the total lipids of $V$. cholerae grown at different temperatures and at different growth phases. The concentration of palmitoleic acid $\left(C_{16: 1}\right)$ increased with increasing temperature in exponential-phase cultures. In contrast the percentage of palmitic acid $\left(\mathrm{C}_{16: 0}\right)$ decreased with increasing temperature in exponentialphase cultures and increased with increasing temperature in stationary-phase cultures. There was a large increase in oleic acid $\left(\mathrm{C}_{18: 1}\right)$ concentration at $37{ }^{\circ} \mathrm{C}$ in stationary-phase cultures and at $27^{\circ} \mathrm{C}$ in exponential-phase cultures.

The fatty-acid distributions in phosphatidylethanolamine, a major phospholipid of $V$. cholerae, in the two growth phases at $37^{\circ} \mathrm{C}$ are given in Table 3. The concentration of palmitoleic acid $\left(\mathrm{C}_{16: 1}\right)$ was higher in phosphatidylethanolamine from stationary-phase cultures whereas the concentrations of palmitic $\left(\mathrm{C}_{16: 0}\right)$ and oleic $\left(\mathrm{C}_{18: 1}\right)$ acids were slightly lower than in exponential-phase cultures.

\section{DISCUSSION}

The phospholipid composition of some eukaryotic micro-organisms is subject to variation depending on the genetic and nutritional state of the organism (Margnall \& Getz, 1973). Our results show that the major phospholipid and fatty acids of $V$. cholerae are dynamic chemical constituents of the bacterial cell. They vary in their relative proportions as well as 


\title{
Table 3. Effect of growth phase on the distribution of total fatty acids in phosphatidylethanolamine of Vibrio cholerae 569B (Inaba)
}

\begin{abstract}
Bacteria were grown at $37^{\circ} \mathrm{C}$ and phosphatidylethanolamine was isolated by thin-layer chromatography as described in Table $I$. The fatty acids in the 2 position were released by snake-venom phospholipase $A_{2}$ and separated by thin-layer chromatography; released fatty acids were methylated and analysed by gas-liquid chromatography as described in Methods.
\end{abstract}

\begin{tabular}{|c|c|c|c|c|c|c|c|c|}
\hline \multirow[b]{2}{*}{$\begin{array}{l}\text { Growth } \\
\text { phase }\end{array}$} & & \multicolumn{7}{|c|}{ Fatty acids* $(\%, w / w$, total fatty acids $)$} \\
\hline & $12: 0$ & $14: 0$ & I 6:0 & $16: I$ & $18: 0$ & I8:I & $\begin{array}{c}\text { Total } \\
\text { sat- } \\
\text { urated }\end{array}$ & $\begin{array}{l}\text { Total } \\
\text { unsat- } \\
\text { urated }\end{array}$ \\
\hline Exponential & 0.3 & $4 \cdot I$ & $50 \cdot 0$ & $25 \cdot 2$ & $2 \cdot 2$ & $18 \cdot 2$ & $56 \cdot 6$ & $43 \cdot 4$ \\
\hline Stationary & 0.3 & 4.5 & $42 \cdot 0$ & $37 \cdot 5$ & $1 \cdot 6$ & 14.0 & $48 \cdot 4$ & $5 I \cdot 5$ \\
\hline
\end{tabular}

* Number preceding the colon indicates the number of carbon atoms; number after the colon designates the degree of unsaturation.

in their actual percentage of the total cell mass both in response to growth temperature and as a function of growth stage. Quantitatively, phosphatidylethanolamine behaved quite differently from phosphatidylglycerol and lyso-phosphatidylethanolamine. Two pronounced changes occurred during the transition of cultures from the exponential to the stationary-growth phase: these were an increase in the proportion of phosphatidylethanolamine, and a decrease in the proportions of phosphatidylglycerol and lysophosphatidylethanolamine. Thus phosphatidylethanolamine synthesis must respond to a different regulatory mechanism than other phospholipids. Changes in the concentrations of phosphatidylethanolamine and phosphatidylglycerol in Escherichia coli (Kanfer \& Kennedy, 1963; De Siervo, 1969) and of phosphoglycerides in Thiobacillus thiooxidans (Shively \& Benson, 1967) follow a similar pattern to those in $V$. cholerae. However, in the Gram-positive Staphylococcus aureus, Short \& White (1970) detected a lower phosphatidylglycerol concentration and a higher cardiolipin concentration in the stationary growth phase than in exponential growth phase.

Decreasing the growth temperature of $V$. cholerae resulted in considerable variation in the relative amounts of the major phospholipids. These results are in agreement with those obtained by Oliver \& Colwell (1973) in Vibrio marinus and Gill (1975) in Pseudomonas fluorescens. However, in Micrococcus cryophilus, the amount and nature of the phospholipids remains constant throughout the growth phases in batch culture, and irrespective of the growth temperature (Russell, 1974). In Escherichia coli the fatty-acid composition of the phospholipids is adjusted in response to growth temperature (Marr \& Ingraham, 1962; Shaw \& Ingraham, 1965; Knivett \& Cullen, 1965; Sinensky, 1971): as the temperature of growth is lowered the proportion of unsaturated fatty acids (chiefly cis-vaccenic acid) in the membrane increases. Recently, Cronan (1975) has shown that the ratio of saturated to unsaturated species appearing in the free fatty-acid fraction depends on the incubation temperature at the time of synthesis of these acids. In $V$. cholerae the variation in the saturated and unsaturated fatty-acid composition with culture age was as great or greater than the variation due to alteration of growth temperature alone. It is also likely that temperature acclimatization involves the reshuffling of the fatty-acid components of the lipids in order to produce lipids of the proper composition. Sinensky (I971) has reported in vivo and in vitro experiments which indicate that the specificity of the enzymes catalysing phospholipid synthesis is altered by temperature change. The synthesis of phospholipids 
therefore seems to be one site of the thermal regulation of fatty-acid composition. Since the lipid composition in many bacteria varies continuously with growth temperature rather than as a step function, it is expected that the temperature effect is mediated at the enzymic rather than the genetic level. Enzymic control, in general, tends to produce a continuous modulation of activity, whereas genetic control does not.

The results reported here are inconsistent with the findings of Gill (1975) that a precise degree of saturation of the lipids is apparently not required for normal growth at high temperature, and the increased saturation of the lipids at these growth temperatures is due to the reduced ability of controlling mechanism to compensate for the effects of environmental changes.

I thank Dr B. B. Gaitonde and Dr S. D. Ambegaokar of the Haffkine Institute, Bombay, India, and Professor T. Kawasaki of the Hiroshima University School of Medicine, Japan, for their guidance and encouragement.

\section{REFERENCES}

Ansell, G. B. \& Hawthorne, J. N. (1964). Phospholipid Chemistry Metabolism and Function, pp. 41 I-419. Amsterdam: Elsevier.

BARTLETT, G. R. (1959). Phosphorus assay in column chromatography. Journal of Biological Chemistry 234, $466-468$.

Bligh, E. G. \& Dyer, W. J. (1959). A rapid method of total lipid extraction and purification. Canadian Journal of Biochemistry and Physiology 37, 91 I-91 7 .

CRONAN, J. E., JR (1968). Phospholipid alterations during growth of Escherichia coli. Journal of Bacteriology 95, 2054-206I.

Cronan, J. E., JR (1975). Thermal regulation of the membrane lipid composition of Escherichia coli. Journal of Biological Chemistry 250, 7074-7077.

Cullen, J., Philips, M. C. \& Shipley, G. G. (1971). The effects of temperature on the composition and physical properties of the lipids of Pseudomonas fuorescens. Biochemical Journal 100, 733-742.

De Siervo, A. J. (1969). Alterations in phospholipid composition of Escherichia coli B during growth at different temperatures. Journal of Bacteriology roo, 1342-1 349.

GiLl, C. O. (1975). Effect of growth temperature on the lipids of Pseudomonas fluorescens. Journal of General Microbiology 89, 293-298.

Hildebrand, J. G. \& LAW, J. H. (1964). Fatty acid distribution in bacterial phospholipids. Biochemistry, New York 3, 1304-1308.

Hunter, K. \& Rose, A. H. (1972). Lipid composition of Saccharomyces cerevisiae as influenced by growth temperature. Biochimica et biophysica acta 260, 639-653.

Kanfer, J. \& KENNEDY, E. P. (1963). Metabolism and function of bacterial lipids. I. Metabolism of phospholipid in Escherichia coli. Journal of Biological Chemistry 238, 2919-2922.

KNIVETT, V. \& CUlleN, J. (1965). Some factors affecting cylopropane acid formation in Escherichia coli. Biochemical Journal 96, 771-776.

Margnall, D. \& Getz, G. S. (1973). Phospholipids. In Lipids and Biomembranes of Eucaryotic Microorganisms, pp. 145-195. Edited by J. A. Erwin. New York, and London: Academic.

MARINETTI, G. V. (1962). Chromatographic separation, identification and analysis of phosphatides. Journal of Lipid Research 3, I-IO.

MARR, A. G. \& InGRAHAM, J. L. (1962). Effect of temperature on the composition of fatty acids in Escherichia coli. Journal of Bacteriology 84, I 260-1 267.

Minnikin, D. E., Abdolrahimzadeh, H. \& Baddiley, J. (1971). Variation of polar lipid composition of Bacillus subtilis (Marburg) with different growth conditions. FEBS Letters 27, I6-I 8.

Minnikin, D. E. \& AbdolrahimzadeH, H. (1974). Effect of $\mathrm{pH}$ on the proportions of polar lipids in chemostat cultures of Bacillus subtilis. Journal of Bacteriology 120, 999-1003.

Morrison, W. R. \& SMITH, L. L. (I964). Preparation of fatty acid methyl esters and dimethyl acetals from lipids with boron fluoride-methanol. Journal of Lipid Research 5, 600-608.

Munro, G. F. \& Bell, C. A. (1973). Effects of external osmolarity on phospholipid metabolism in Escherichia coli B. Journal of Bacteriology 116, 257-262.

Oliver, J. D. \& Colwell, R. R. (1973). Extractable lipids of Gram-negative marine bacteria: phospholipid composition. Journal of Bacteriology II4, 897-908. 
Randle, C. L., Albro, P. W. \& Dittmer, J. C. (1969). The phosphoglyceride composition of Gramnegative bacteria and the changes in composition during growth. Biochimica et biophysica acta 187, 214-220.

Raziuddin, S. \& Ambegaokar, S. D. (1976). Lipids of Vibrio cholerae. Japanese Journal of Microbiology (in the Press).

Raziuddin, S. \& KaWASAKI, T. (1976). Biochemical studies on the cell wall lipopolysaccharides (O-antigen) of Vibrio cholerae 569B (Inaba) and El-tor (Inaba). Biochimica et biophysica acta 431, I I6-I 26.

RizzA, V., Tucker, A. N. \& White, D. C. (1970). Lipids of Bacteriodes melaninogenicus. Journal of Bacteriology ror, 84-9I.

Russell, N. J. (197I). Alteration in fatty acid chain length in Micrococcus cryophilus grown at different temperatures. Biochimica et biophysica acta 23I, 254-256.

Russell, N. J. (1974). The lipid composition of psychrophilic bacterium Micrococcus cryophilus. Journal of General Microbiology 80, $217-225$.

Shaw, M. K. \& Ingraham, J. L. (1965). Fatty acid composition of Escherichia coli as a possible controlling factor of the minimal growth temperature. Journal of Bacteriology 90, I4I-I46.

Shively, J. M. \& Benson, A. A. (1967). Phospholipids of Thiobacillus thiooxidans. Journal of Bacteriology 94, $167-168$.

ShorT, S. A. \& White, D. C. (1970). Metabolism of phosphatidylglycerol, lyso-phosphatidylglycerol and cardiolipin of Staphylococcus aureus. Journal of Bacteriology 108, 219-226.

SiNENSKY, M. (I971). Temperature control of phospholipid biosynthesis in Escherichia coli. Journal of Bacteriology ro6, 449-455.

Vorbeck, M. L. \& MARINETti, G. V. (1965). Separation of diglycerides from phosphatides using silicic acid column chromatography. Journal of Lipid Research 6, 3-6. 